УДК 811.163.41'342.9

$811.163 .41^{\prime} 367.32$

https://doi.org/10.18485/msc50.2021.2.ch46

Јелица Јокановић-Михајлов

\title{
ИНТОНАЦИОНЕ КАРАКТЕРИСТИКЕ И ГРАМАТИЧКИ ОПИС РЕЧЕНИЦА ОБЕЛЕЖЕНИХ ЗНАКОМ УЗВИКА
}

На једном од наших претходних научних састанака, разматрали смо интонацију оних реченичних структура за које је и новија граматичка литература задржала традиционални назив узвичне реченице (Јокановић-Михајлов 1999), а овде ће бити речи о истраживању којим смо обухватили друге, овима сродне реченичне структуре, које би такође могле бити третиране као узвичне, што је делом и чињено у старијим граматикама, а које су у новијим описима добиле друго место и другу интерпретацију. И једне и друге се у начелу једнако правописно обележавају - знаком узвика; и за једне и за друге се у граматици истиче важност интонационог обликовања па им се и интонација најчешће помиње као узвична, али се сада само прве сматрају узвичним реченицама, а друге не. Примера ради, према овој подели, какву имамо рецимо у савременој Граматици српскога језика (Поповић ${ }^{72000), ~ р е ч е н и ц е ~ Ш т о ~ с и ~ д о с а д а н ! ~}$ и Ала си досадан! јесу, а реченице Ужасно си досадан! и Баш си досадан! нису узвичне. Очигледно је да примењени граматички опис, који је у првој верзији био намењен средњошколској популацији, тежи да нађе једноставан и лако уочљив критеријум за класификацију комуникативних функција независних реченица. Тежња је очигледно била да се да класификација која се, с једне стране, може лако применити и када је пред нама писани текст (не мора се дакле удубљивати у интонациону структуру и ослушкивати „како то звучи”), а с друге стране, очигледно се хтело постићи и да ученици, без великих напора лако могу запамтити параметре који су у основи класификације. Ово последње је посебно драгоцено у ситуацији када су ученици улагању напора, из генерације у генерацију, све мање склони. Тако практични и једноставни критеријуми су нађени у формалној структури реченица, у јасним и лако уочљивим синтаксичким и лексичким обрасцима. На основу њих ученик, претпоставља се, врло лако разврстава реченице и добија изложену поделу на обавештај- 
не, упитне, заповедне, желне и узвичне реченице. Уз описе реченичних структура, свуда је, где се то сматрало битним, додавано обавештење о важности интонационе компоненте, али је она, као другостепена, само помињана а не описивана. Илустрације добрим реченичним примерима су свуда присутне, али су примери појединачни. Обим материјала Граматике је, како и обавезује њен уџбенички карактер, нужно ограничен, па се уз дате моделе примери наводе штедљиво. Ово значи да је биран само један тип међу могућим репрезентима једног модела, а то је често недовољно за његово потпуно представљање. Тако се за тзв. обавештајне експресивне реченице, које нас овде посебно интересују, каже следеће: „Употребом узвичне интонације односно узвичника обавештењу се придаје експресивни карактер, тј. показују се говорникове емоције у вези са оним што садржи реченица; пример Иван је дошао!" (Поповић ${ }^{7} 2000$ : 342) Овај (једини) пример је дакле везан за емоције.

И раније граматике појам узвичних реченица везују за емоционалну сферу, пре свега. Код А. Белића налазимо: „Ускличне су реченице у којима се износи расположење, осећање итд.” и даље, „иначе се употребљавају уз усклике, којима се износи главни део њихова значења". Као примери се наводе овакве реченице: А какав је Скадар на Бојани! или Колико има времена да те чекам! (Белић 2000: 286). Бранко Милетић гледа на ову проблематику из свог, фонетског (у ужем смислу речи) угла, па узвичне реченице помиње само узгред и то једино у вези са каденцама: „Узвичне мелодије имају у принципу исти ток мелодије као реченице са апсолутном паузом - мелодија се према крају спушта" (Милетић 1952: 95). Код Михаила Стевановића имамо јасно везивање узвичних реченица за сферу јаких емоција; њима се „изражава силина осећања у изузетним психичким расположењима изазваним сликом реалности" (Стевановић 1989: 20). Он их ипак не сматра посебном врстом реченица, већ су то само емоцијама модификоване обавештајне и упитне реченице. А тзв. желье, вољне и императивне реченице код њега су дате у склопу сложених (зависносложених) реченица, са помињањем могуће самосталне употребе, док су у граматици Ж. Станојчића и Љ. Поповића оне и обрађене као типови независних реченица, где једино и могу имати тзв. узвичну интонацију.

Када ученицима или студентима предложите да изговоре неку обавештајно-експресивну реченииу као што је Иван је дошао!, они, супротно очекивањима, почињу да се колебају и не полази им за руком да је интонирају како се захтева, упркос ширини избора који им је остављен - да то може бити било која емоција и било каква експресија. На питање какву емоцију претпостављају и како би контекстом допунили и разјаснили значење дате реченице, најчешће се помињу: радост, задовољство и 
изненађење, а као контексти се нуде: уз радост и задовольство - „то ми је драго” и „мило ми је”, а уз изненађене - „а рекао је да неће” и „очекивали смо га тек сутра" и сл.

Препознавање реченице према изговору друге особе или са снимка, знатно је успешније. То значи да у добро интонираној реченици слушалац лако препознаје њен карактер, али да сам има потешкоћа да га искаже само на основу формалног обележја (знака узвика) и синтаксичког облика. За реченицу Иван је дошао! као најприроднији од неколико предложених контекста оцењен је онај са значењем „кренимо му у сусрет” и „дочекајмо га”. А то већ није емоција него активирање сабеседника, подстицање на активност. Код већине сличних примера, када говоре на основу наученог, ученици и студенти које смо анкетирали, најпре помињу емоције, али у препознавању изговореног на основу језичког осећања функција подстицања и активирања стоји испред емоција. Ово нам за сада показује две ствари: прво, да значења која одвајају ове реченице од обавештајних нису нужно везана за емоције и друго, да је њихова реализација преко интонационих параметара градуелна и директно зависна од контекста. Говорник се зато и устеже да их звуком илуструје, уколико није у стању да брзо замисли тачан контекст, у коме се оне могу природно појавити.

Непосредни повод за разматрање непоклапања језичког осећања и граматичког описа узвичних реченица дали су овогодишњи одговори кандидата - будућих студената, на пријемном испиту из српског језика. Непоклапање њихових одговора са описима из граматике не би привлачило нашу пажњу кад би била реч о недовољно припремљеним кандидатима. Ми овде имао у виду само одговоре оних који су на сва друга питања у тесту тачно одговорили и чије су једине грешке и биле процена реченица са знаком узвика. У наставку ћемо анализирати, између осталог, и реченице са овог теста.

Како се у ствари гласом могу преносити емоције и, да се послужимо Стевановићевом формулацијом, „силина осећања у изузетним психичким расположењима"? Најчешће емоције које модификују изговор и реченичну интонацију и утичу на приметну измену више дикцијских карактеристика су: страх, радост, чуђење, увређеност, гнев; затим туга, разнеженост, равнодушност (Цеплитис 1974: 186). Уочљива је физичка, тачније физиолошка основа њихове појаве, а то су различите измене артикулације, које настају без наше воље и трају све док говоримо под утицајем јаке емоције. Услед овог, измењени интонациони параметри боје исказ у целини, распростиру се на све његове сегменте. Тако на пример, код страха имамо, између осталог, тзв. пулсирајућу експирацију и стака- 
то артикулацију, а код радости - велики опсег мелодијског кретања, са приметним и брзим мењањем интервала у оквиру њега итд. Елементи овакве интонације постоје и приметни су као општи утисак о дикцији оствареној под јаким емоцијама, али то није толико често, колико смо склони да претпоставимо, полазећи од (у граматичким описима) наглашеног везивања узвичних реченица за манифестације емоционалног стања говорника.

Погледаћемо сада какву интонацију имају парови реченица са идентичним обликом и лексичким саставом, од којих ће прва увек бити обележена знаком узвика а друга тачком. Ево првог пара:

Долази Иван! - Долази Иван.

Најуочљивија разлика је у мелодији: она је у првом случају у облику изразитог лука, са великим успоном и великим падом, а у другом је блага, са једва приметним успоном и изразитим, али постепеним падом до краја. Интензитет је већи у првом случају, али ни у другом није мали. Значајнија од апсолутних вредности интензитета је разлика у његовој распоређености: код узвичне варијанте је неуједначена (јачи је на првој речи), а код обавештајне је сасвим уједначена. Трајања реченица се битније не разликују, мада је узвична нешто дужа. На семантичком плану узвична варијанта се процењује као обраћање пажње, подстицање на активност, са могућим контекстом „тишина, ево га”, „умирите се”, „припремите се” и сл. У пару реченица

Дан је фантастичан! - Дан је фантастичан.

имамо скоро истоветну мелодијску разлику као и у претходном пару; и овде мелодија прави велики, изразити лук, наспрам једва приметног успона и равномерног пада у обавештајној варијанти. Овде је, међутим, интензитет друкчије распоређен него у претходном пару: овде је неуједначеност присутна у обавештајној, а изразита, равномерно распоређена енергија у узвичној. Томе се додаје и посебна експресивност, која се одмах уочава при слушању, а постигнута је специфичним успоравањем темпа на првом слогу речи фантастичан и скоро обезвученим назалом на крају овог слога. Тиме се постиже значење субјективног вредновања, давања оцене, а не, како се традиционално тумаче овакви случајеви као чисто или искључиво исказивање задовољства или радости. Ако су, што је често случај, оба значења присутна, евалуативна компонента је претежнија од емотивне. Присуство ове последње је обично везано за додатне промене у тонском регистру, па и у спектру гласова. 
Ево сада примера класичне, праве узвичности, дакле оне која исказује пре свега неку емоцију. Овде је то изненађење, неверица, чак згранутост, све у зависности од изговорене варијанте. Овај пар чине реченице

Цео дан пада киша! - Цео дан пада киша.

Интересантно је да су тонске линије скоро идентичне, с тим што узвична почиње врло високо, дуго остаје у високом регистру и у њему остварује и постепени пад на крају, а обавештајна све то остварује у средњем регистру и уз нешто мањи интензитет. Распоред интензитета унутар реченица показује разлику коју смо већ описали у једном од претходних примера и која се показује као карактеристична за овакве парове - код узвичне реченице енергија није, а код обавештајне јесте равномерна, а карактеристично је и нешто дуже трајање узвичне реченице у односу на обавештајну. Ево још једног пара реченица са класичном узвичношћу, дакле са исказивањем емоција. Овде је то изненађење са нијансом задовољства, а начин како је ово остварено интонацијом поклапа се са паром који смо управо описали. Када се прва реченица изговори са нијансом подстицања на активност, као претпостављени контекст најчешће се наводи садржај типа „ово је невероватно, гледај”:

\section{Цртежи су потпуно исти! - Цртежи су потпуно исти.}

У следећем пару, који се уобичајено тумачи као исказивање емоција, у ствари претеже исказивање оцене:

\section{Копа бунар! - Копа бунар.}

Контекст и значење које можемо претпоставити нису „нервирам се”, „љути ме” него, рецимо: „ипак копа а рекли смо му да је терен безводан”, „зна да нема воде а копа” и сл.

Ово су све били парови у којима су реченице обележене знаком узвика биле окренуте или субјективном вредновању, давању оцене, или подстицању на активност, обраћању пажње, или пак класичном исказивању осећања, односно комбиновању неких од поменутих значења. Својим лексичким садржајем оне, наравно, доносе и информацију, али им информисање није основна комуникативна функција. А према граматичкој класификацији оне припадају типу не узвичних него обавештајних реченица. То што се њихов лексичко-синтаксички склоп поклапа са правим обавештајним реченицама, а интонациона структура са узвичним у широком смислу појма, послужило је као основа за формално сврставање у обавештајне реченице, али није могло утицати на наше 
језичко осећање, које их као такве не доживљава, јер се оно базира на семантици, те полази од садржаја ка форми, а не обрнуто. Баш као што се код реченица које имају потпуно обличко поклапање са обавештајним реченицама, али посебну интонацију која их чини упитним, наше језичко осећање сасвим лепо оријентише и доживљава их као лако препознатљиве упитне моделе (Путујеш у суботу? према Путујеш у суботу. или Положила си књижевност? према Положила си књижевност.), тако и овде имамо форму која се поклапа са обавештајним реченицама, али значење које није обавештење и које је, једнако као и код поменутих упитних реченица исказано - интонацијом.

У још једној новој граматици, овог пута основношколској, у потпуности се преузима синтаксичка интерпретација из граматике Ж. Станојчића и Љ. Поповића, па се и према њој реченице по форми обавештајне, могу изговорити са узвичном интонацијом (и обележавају се знаком узвика), исказују изненађење, радост и слично, али - нису узвичне него обавештајне (Кликовац 2002). Свакако да компонента информације јесте присутна у реченици као што је Данас је прелеп дан!, али је иста информација присутна и у Како је данас леп дан!. Како се полази од форме а не од садржаја, прва се сматра обавештајном а друга узвичном. То се коси са учениковим језичким осећањем и не само учениковим. Класификација каква је дата у овим граматикама веома је корисна за анализу синтаксичких структура, за уочавање средстава којима се служимо у формирању најразличитијих исказа, али би се побољшала ако би укључила или паралелно дала и класификацију према семантичким критеријумима. Они јесу примарни у свести говорника и то показују поменути примери из јунског теста на пријемном испиту, где су матуранти, који су имали само по једну грешку, ту грешку направили код комуникативне функције реченица са знаком узвика. А добар део слабијих ученика, за које се по одговорима на друга питања види да имају и слабије знање и слабије језичко осећање, и који су се зато очигледно ослањали на визуелну процену и на интерпункцију, дао је тражене одговоре. Тако је било и са примером Стижу нам гости! који ћемо сада посматрати. Више је нијанси изговора ове реченице, разуме се. Ако се иде на експресивни изговор, на шта упућује интерпункција, два су основна вида: први, који износи осећање говорника или групе којој припада, рецимо, осећање радости због доласка драгих гостију и други, који има једно од подстицајних значења, какво је, на пример, пожуривање укућана да прекину ситне послове и крену у сусрет гостима и сл. И једно и друго, укључујући нијансе у којима се конкретна варијанта остварује, носи узвичност као доминантно обележје. У првом случају ће осећање радости бити исказано интонаци- 
оним средствима која смо већ поменули као типична за исказивање емоција (висок почетак, горњи регистар, напрегнута артикулација, повећан интензитет). У другом случају, зависно од контекста, подстицање може ићи од благог до паничног, што ће у интонационом смислу бити исказано разликом у тонском регистру и укупном енергијом говорног сигнала. У оба случаја узвичност ће бити јасна и доминантна. Могућа варијанта ове реченице, која би гласила Ево нам гостију! и која би носила исту узвичност и иста значења, због карактеристичног синтаксичког облика не би у поменутој граматичкој интерпретацији била сматрана узвичном, иако те карактеристике има, већ тзв. специјалном независном реченицом. Да је ствар са специјалним независним реченицама, које све имају интонационо обележје узвичности и одговарајућу интерпункцију, тешко ускладива са језичким осећањем, будући да су због потреба анализе синтаксичких структура оне раздвојене од других конструкција истог или блиског значења, показује и чињеница да се у поменутој основношколској граматици од њих одустало и да се тамо и не помињу. Ако се у граматике дода и класификација према реалним значењима и ако се укаже на синонимност појединих конструкција, онда ће њихова формална класификација само добити на вредности. То је и намера наше анализе.

Јасно је да и тзв. заповедне или императивне реченице у великом броју случајева уопште не исказују заповест него читав спектар подстицајних садржаја, а у литератури се за друге језике помиње преко седамдесет њихових нијанси. Термин заповедне је зато збуњујући јер никако не одговара исказивању молби, предлога, наговора, упозорења и сличних честих садржаја, а његов синоним императивне је свакако бољи, јер се бар може тумачити као „реченице са обликом императива” а са врло различитим значењима.

\section{ЦИТИРАНА ЛИТЕРАТУРА}

Јокановић-Михајлов 1999: Категорија узвичности - прозодијска структура и реченични модели, Научни састанак слависта у Вукове дане, 28/2, 119-126.

Поповић ${ }^{7} 2000$ : Живојин Станојчић, Љубомир Поповић, Граматика срискога језика, уџбеник за I, II, III и IV разред средње школе, Београд: Завод за уџбенике и наставна средства.

Белић 2000: Александар Белић, Универзитетска предаваюа из савременог српскохрватског језика, Изабрана дела А. Белића, књ. 14, Београд: Завод за уџбенике и наставна средства. 
Милетић 1952: Бранко Милетић, Основи фонетике српског језика, Београд: Знање.

Стевановић ${ }^{4}$ 1989: Михаило Стевановић, Савремени српскохрватски језик, II Синтакса, Београд: Научна књига.

Цеплитис 1974: Л. К. Цеплитис, Анализ речевой интонации, Рига.

Кликовац 2002: Душка Кликовац, Граматика српскога језика за основну школу, Београд: Српска школска књига.

Елица Йоканович-Михайлова

ИНТОНАЦИОННЫЕ ХАРАКТЕРИСТИКИ И ГРАММАТИЧЕСКОЕ ОПИСАНИЕ ПРЕДЛОЖЕНИЙ С ВОСКЛИЦАТЕЛЬНЫМ ЗНАКОМ

Резюме

В данной работе анализируются предложения с восклицательным знаком и описываются их интонационнные и семантические свойства. Все это сопоставляется с существующим грамматическим описанием и соответствующей классификацией данных предложений. Констатируется расхождение между восприятием этих предложений на основе чувства эзыка и восприятием на основе грамматического описания. 